would not allow the United States to launch what the Soviet Union fears most, a first strike against military targets. That is why it matters that SDI will probably also give the United States some facility for destroying Soviet missiles in flight, most probably not by fancy laser technology but by more old-fashioned ways of destroying unwanted objects. Mr Reagan seems unreasonably insensitive to Soviet suspicions that, in this guise, SDI would be a convenient umbrella for a first strike.

This, a constant theme at the negotiations at Geneva, and probably also at Reykjavik, has been a serious issue from the outset. Mrs Margaret Thatcher, the British Prime Minister, went to Washington three years ago to secure a promise that SDI is, for the time being, a research programme only; then, as now, the United States seemed not properly to appreciate that, without such an understanding, SDI research could do endless damage. Mrs Thatcher's understanding of "research" may have been different from Mr Gorbachev's, but they have been making the same point. (If the United States concedes that the Soviet Union is entitled to some assurance on the point, should it not also concede the need for verification of SDI, one of the constant complaints at Soviet proposals for arms control?) But $\mathrm{Mr}$ Reagan's statement to the United Nations last month (see $\mathrm{Na}$ ture 323, 381; 1986) was a more explicit account than previously of the obligations the United States would assume.

So what went wrong at Reykjavik? On the face of things, the gap between the two sides could have been bridged by negotiation. The objective should have been to find a way of containing the SDI programme within reasonable limits for the time being, with the understanding that the future of the project would be decided at some pre-set date. This position, not very different from what Mr Reagan offered at the United Nations or from what $\mathrm{Mr}$ Gorbachev was asking at the weekend, would have allowed Mr Reagan to continue making speeches about the need to abolish the threat of nuclear weapons and $\mathrm{Mr}$ Gorbachev to keep on saying that SDI is an abomination. History will tell whose small point of principle proved insurmountable at Reykjavik, and whether it was worth the trouble it will cause.

What will that be? The immediate danger is a shouting-match, a return to the early $1980 \mathrm{~s}$. Both sides have learned too much for that to happen. But the abandonment of the Geneva talks, which would not surprise despondent post-Reykjavik George Shultz, the US Secretary of State, would be a bad sign. The middle-term danger is what it has always been, that relationships between the two superpowers will deteriorate to the point at which war in Europe, with all its new-fangled engines, comes to seem again an ever-present threat. But is that not the case now? The oddest feature of the past few years is that, while the names that the two sides have called each other have been no more tolerable than in previous decades, war in Europe has seemed less imminent. Why should that be? Because the Soviet government, whatever its intentions, has found it necessary to relax its supposition that the world is divided into two by the Elbe.

People on both sides of the mutual German frontier now have a more vivid understanding of what the others have to offer. In the technical community, the continuing sad isolation of Soviet science is nothing less than tragic - for both sides. A week or so after the release of Orlov from prison (and his unkind expulsion from the Soviet Union), it is worth remembering that even arms control is merely a means to ends still undefined.

\section{Underpaid and overtaxed}

\section{The 1986 Tax Reform Act will make the United States even more a magnet to technical people.}

A FEw days after President Ronald Reagan signed into law the 1986 Tax Reform Act, the British Chancellor of the Exchequer, Mr Nigel Lawson, was last week telling the annual conference of the Conservative (and government) Party that he still intends to see the basic rate of income tax, at present 29 per cent, reduced to 25 per cent. Under the British system, the basic rate is that which affects or afflicts most taxpayers; those who earn substantially more than the average salary pay at a higher rate (at the margin) up to a maximum of 60 per cent. Mr Lawson's declaration appears to have been ecstatically received, not least as a sign that the British government is sticking by its seven-year-old election promise. But neither he nor his audience appears to have noticed that the effect of the US Tax Reform Act is to reduce the highest rate of personal taxation in the United States to below what the British chancellor must for the time being call "standard". Nothing could more starkly illustrate the differences between these two English-speaking countries, or the reasons why one of them is economically and even technically more successful than the other.

To be fair, the Tax Reform Act is not the unalloyed blessing it may seem from a distance. Many of the tax shelters in which the middle classes of the United States have tucked their savings will in future be taxable, while there will also be limits on the amounts of interest paid (except on mortgages on first and second homes) that may be set off against income before the computation of tax. Medical and educational spending (above certain limits) will not in future be wholly a charge on the US Internal Revenue Service (better known as IRS), while there will be extra costs to pay for state and local taxes. The restraints on what counts as a charitable deduction from income will hurt some charitable institutions, universities among them, while there is nothing in the tax bill to help reduce the budget deficit (which would require an upper rate more like 30 than 28 per cent). The interim plan that corporations should pay taxes at a higher rate ( 32 per cent) could damage economic growth, but there is an army of accountants and corporate treasurers seeking ways round that obstacle. What the reform act will do is to confirm the general impression of what is the reality, that the United States is a low-tax society. That will further exacerbate a string of problems with which the high-tax societies of Western Europe have been living for several years.

The chief of these is the readiness of technical people to move from one place to another. For the past two decades, successive British governments have been wringing their hands over the rate at which technically trained people have departed for the United States, usually with seemly protestations that they are not going for the money but for the professional opportunities but in the certain knowledge that their skills will also command a higher price. Prudent would-be emigrants from Western Europe, to be sure, have always known that the balance of advantage is not calculable by simple arithmetic; even in Britain, the value of the social benefits provided by what the American Medical Association calls "socialized medicine", for example, are far from negligible. But the Tax Reform Act cannot but accelerate the emigration, at least while tighter US immigration laws seem not seriously to have restricted the freedom of US organizations to hire skills in short supply (nor should they).

How will Mr Lawson and his government colleagues respond to that prospect? The obvious danger is that they will think it unimportant. They may also, plausibly, complain that it would be ridiculous, and economically impractical in any case, for the government of Britain or some other Western European state to amend its own taxation policy so as to compete more effectively with the United States for the allegiance of a small proportion of its population. But that, unfortunately, is only half the story. With time, the market in technically qualified labour is bound to become more international and more free. In the long run, places that underpay and overtax their technical people will find themselves left only with those who lack the qualifications to get up and go, hardly the best guarantee of technical or economic success. So, in the long run, there is a sense in which $\mathrm{Mr}$ Lawson (or his successors) will have no choice but to emulate the US 1986 Tax Reform Act. That is yet another reason for believing that this piece of legislation may be the most enduring and influential monument to the Reagan administration. 